\title{
Selective cardiac sympathetic blockade as an adjunct to bronchodilator therapy
}

\author{
RAYMOND POWLES, ELLIOT SHINEBOURNE, AND \\ JOHN HAMER
}

From the Cardiac Department, St. Bartholomew's Hospital, London E.C.I

It has been shown in nine asthmatic patients that practolol, a selective cardiac beta-adrenergic antagonist, successfully blocks the unwanted tachycardia and palpitation following isoprenaline inhalation without hindering the beneficial bronchodilator action of the drug. Practolol is a useful adjunct to bronchodilator therapy in the management of bronchial asthma.

Attention has recently been directed to the possible lethal effect of aerosol sympathomimetic agents in the treatment of bronchial asthma (Speizer, Doll, Heaf and Strang, 1968), death being attributed to an excitatory action on the heart. Animal studies indicate that practolol (I.C.I. 50,172, Eraldin) specifically blocks cardiac beta-adrenergic receptors, preventing arrhythmias or other alterations in cardiac function, but does not interfere with the bronchodilator actions of sympathetic amines (Dunlop and Shanks, 1968). We have investigated the ability of I.C.I. 50,172 to protect the hearts of asthmatic patients from the excitatory action of sympathomimetic drugs.

\section{METHODS}

Nine patients aged 18 to 61 years with chronic, but partly reversible, airways obstruction were studied; none had significant cardiovascular disease (Table I). All treatment was withheld on the night and morning before the investigation. The patient was connected to an electrocardiograph, for measurement of

T A B L E I

\begin{tabular}{|c|c|c|c|c|c|}
\hline Patient & Sex & Age & Diagnosis & $\underset{\text { (yrs) }}{\text { Duration }}$ & Treatment \\
\hline $\begin{array}{l}\text { J.S. } \\
\text { A.E. } \\
\text { V.J. }\end{array}$ & $\underset{\mathbf{F}}{\mathbf{M}}$ & $\begin{array}{l}18 \\
39 \\
43\end{array}$ & $\begin{array}{l}\text { Extrinsic asthma } \\
\text { Extrinsic asthma } \\
\text { Chronic bronchitis } \\
\text { Intrinsic asthma }\end{array}$ & $\begin{array}{r}6 \\
30 \\
3\end{array}$ & $\begin{array}{c}\text { Bronchodilators } \\
\text { Bronchodilators } \\
\text { Prednisolone, } \\
12.5 \mathrm{mg} \text {, daily }\end{array}$ \\
\hline $\begin{array}{l}\text { P.H. } \\
\text { M.S. }\end{array}$ & $\underset{\mathbf{F}}{\mathbf{M}}$ & $\begin{array}{l}46 \\
47\end{array}$ & $\begin{array}{l}\text { Extrinsic asthma } \\
\text { Extrinsic asthma }\end{array}$ & $\frac{3 / 12}{7}$ & $\begin{array}{l}\text { Bronchodilators } \\
\text { Steroids up to three } \\
\text { months prior to } \\
\text { test }\end{array}$ \\
\hline W.B. & $\mathbf{F}$ & 49 & Extrinsic asthma & 6 & $\begin{array}{l}\text { Steroids stopped } \\
\text { three weeks prior } \\
\text { to test }\end{array}$ \\
\hline $\begin{array}{l}\text { E.M. } \\
\text { W.C. } \\
\text { F.C. }\end{array}$ & $\begin{array}{l}\mathbf{F} \\
\mathbf{M}\end{array}$ & $\begin{array}{l}56 \\
59 \\
61\end{array}$ & $\begin{array}{l}\text { Extrinsic asthma } \\
\text { Extrinsic asthma } \\
\text { Chronic bronchitis } \\
\text { Emphysema } \\
\text { Intrinsic asthma }\end{array}$ & $\begin{array}{r}30 \\
10 \\
4\end{array}$ & $\begin{array}{l}\text { Bronchodilators } \\
\text { Bronchodilators } \\
\text { Bronchodilators }\end{array}$ \\
\hline
\end{tabular}

the pulse rate and to detect any arrhythmia, and was $\stackrel{\mathbb{D}}{3}$ then allowed to reach a resting state whilst seated in the laboratory.

A control pulse rate was measured, and three esti- $\vec{\bullet}$ mations of the forced expiratory volume in one second 8 (F.E.V.1.0) were made using a Vitalograph (Godart); the mean of these figures was used in the subsequent calculations. Four full inspirations of a $4 \%$ isoprenaline aerosol were then taken from a Wright'so nebulizer with an air flow of $81 . / \mathrm{min}$. using a stan-0ू dard technique (Chamberlain, 1967). The resultant $\stackrel{\varnothing}{\varrho}$ tachycardia was estimated after $45 \mathrm{sec}$., and the mean $\overrightarrow{\vec{P}}$ of three F.E.V.1.0 estimations was taken once more. $\frac{3}{3}$

After $30 \mathrm{~min}$. rest, when the control pulse rate and F.E.V.1.0 had returned to a steady value, the entire procedure was repeated. On this occasion a slow intravenous injection of $20 \mathrm{mg}$. of I.C.I. 50,172 was given $\vec{\partial}$ prior to the isoprenaline inhalation and the change $\frac{O}{d v}$ in pulse rate and mean F.E.V.1.0 was noted. The $\times$ effect of the inhalation of isoprenaline on the pulse rate and F.E.V.1.0 was then measured as before. To avoid the effort tachycardia produced during estima- $\delta$ tion of F.E.V.1.0, the pulse rates were always measured first. Symptomatic changes, such as palpitations and 0 headache, and all cardiac arrhythmias were noted.

\section{RESULTS}

The variations in pulse rate and F.E.V when an isoprenaline aerosol is inhaled with and without intravenous I.C.I. 50,172 are shown in Tables II O and III. The statistical significance of these results 0 is also tabulated. I.C.I. 50,172 significantly slows $\frac{\text { }}{\varnothing}$ the resting pulse rate and profoundly depresses $\stackrel{?}{+}$ isoprenaline-induced tachycardia. The mean in- 0 crease in pulse rate after isoprenaline in patients who had received I.C.I. 50,172 was only 6 beats $/ \stackrel{\mathbb{D}}{\Omega}$ min. compared with 26 without I.C.I. 50,172. In $\mathbb{8}$ spite of the half-hour rest, the initial F.E.V. $\cdot_{1 \cdot 0}$ was 616 
T A B L E I I

PULSE RATES PER MINUTE

\begin{tabular}{|c|c|c|c|c|c|}
\hline Patient & $\begin{array}{c}\text { First } \\
\text { Control }\end{array}$ & $\begin{array}{c}\text { After } \\
\text { Iso- } \\
\text { prenaline }\end{array}$ & $\begin{array}{l}\text { Second } \\
\text { Control }\end{array}$ & $\begin{array}{l}\text { After } \\
\text { I.C.I. } \\
\text { 50,172 }\end{array}$ & $\begin{array}{c}\text { After } \\
\text { Iso- } \\
\text { prenaline }\end{array}$ \\
\hline 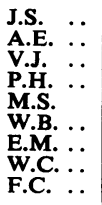 & $\begin{array}{r}110 \\
74 \\
115 \\
103 \\
104 \\
93 \\
104 \\
104 \\
106\end{array}$ & $\begin{array}{l}143 \\
111 \\
124 \\
136 \\
117 \\
152 \\
121 \\
121 \\
124\end{array}$ & $\begin{array}{r}119 \\
75 \\
113 \\
120 \\
112 \\
94 \\
104 \\
99 \\
113\end{array}$ & $\begin{array}{l}96 \\
80 \\
88 \\
84 \\
81 \\
77 \\
70 \\
79 \\
88\end{array}$ & $\begin{array}{r}104 \\
86 \\
86 \\
98 \\
83 \\
78 \\
88 \\
88\end{array}$ \\
\hline Mean & 101 & $\begin{array}{c}128 \\
P<0.01\end{array}$ & 105 & $\begin{array}{c}83 \\
P<0.001\end{array}$ & $\begin{array}{c}89 \\
P<0.05\end{array}$ \\
\hline
\end{tabular}

T A B L E I I I

F.E.V.1.0 IN LITRES

\begin{tabular}{|c|c|c|c|c|c|}
\hline Patient & $\begin{array}{c}\text { First } \\
\text { Control }\end{array}$ & $\begin{array}{c}\text { After } \\
\text { Iso- } \\
\text { prenaline }\end{array}$ & $\begin{array}{l}\text { Second } \\
\text { Control }\end{array}$ & $\begin{array}{l}\text { After } \\
\text { I.C.I. } \\
\text { 50,172 }\end{array}$ & $\begin{array}{c}\text { After } \\
\text { Iso- } \\
\text { prenaline }\end{array}$ \\
\hline 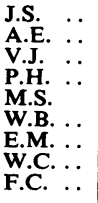 & $\begin{array}{l}0.60 \\
1.35 \\
0.55 \\
0.85 \\
2.00 \\
0.95 \\
0.35 \\
0.85 \\
0.65\end{array}$ & $\begin{array}{l}0.90 \\
1.65 \\
1.40 \\
1.25 \\
2.00 \\
1.95 \\
0.55 \\
1.45 \\
0.80\end{array}$ & $\begin{array}{l}0.80 \\
1.60 \\
0.95 \\
1.05 \\
2.10 \\
1.85 \\
0.50 \\
1.40 \\
0.75\end{array}$ & $\begin{array}{l}0.80 \\
1.35 \\
0.55 \\
0.85 \\
2.10 \\
1.55 \\
0.45 \\
1.35 \\
0.50\end{array}$ & $\begin{array}{l}0.95 \\
1.90 \\
1.30 \\
1.15 \\
2.10 \\
1.90 \\
0.55 \\
1.70 \\
0.80\end{array}$ \\
\hline Mean & 0.90 & $\begin{array}{c}1.35 \\
P<0.01\end{array}$ & $1 \cdot 20$ & $\begin{array}{c}1.05 \\
P<0.01\end{array}$ & $\begin{array}{c}1.35 \\
P<0.01\end{array}$ \\
\hline
\end{tabular}

higher in the second part of the study, suggesting some persistent bronchodilator effect. I.C.I. 50,172 depressed the resting F.E.V $\cdot_{1 \cdot 0}$ but did not prevent a rise in F.E.V..$_{1 \cdot 0}$ after isoprenaline. Although the increase in F.E.V. $\cdot_{1 \cdot 0}$ after isoprenaline was less when I.C.I. 50,172 was given, the final F.E.V.1•0 was similar in the two parts of the study.

No patient experienced any side effects, immediate or delayed, from the intravenous injection of I.C.I. 50,172. Five patients experienced palpitations and two patients developed a pounding in the head after inhaling isoprenaline without intravenous I.C.I. 50,172, whereas only one patient had minimal discomfort when protected by the drug. One patient developed ventricular extrasystoles when inhaling isoprenaline but this did not recur when the inhalations were repeated after I.C.I. 50,172 .

\section{DISCUSSION}

The discovery of derivatives of isoprenaline such as pronethalol and propranolol that specifically block all beta-adrenergic receptor sites did much to support Ahlquist's (1948) classification of adrenergic receptors. Recently, a similar compound, 4-(2-hydroxy-3-isopropyl-aminopropoxy) acetanilide, I.C.I. 50,172, has been discovered which is an adrenergic receptor antagonist with a much greater degree of specificity for cardiac than for other beta-receptors. The beta-adrenergic sites of the smooth muscle of the bronchi and trachea are relatively unaffected by this drug. Animal experiments have shown that I.C.I. 50,172 blocks the action of both adrenaline, the natural sympathetic transmitter, and isoprenaline, which is a synthetic beta-sympathetic stimulating agent.

In the present study it was found that infusion of I.C.I. 50,172 produced significant slowing of the resting pulse rate (from a mean of 101 per minute to a mean of 83 per minute), contrary to the finding in anaesthetized cats and dogs, which show little change in heart rate with infusions of I.C.I. 50,172 (Dunlop and Shanks, 1968), and the study of Brick, Hutchison, McDevitt, Roddie, and Shanks (1968) who found that I.C.I. 50,172 administered to healthy volunteers in doses of 5 to $20 \mathrm{mg}$. produced little change in heart rate. This difference may be due to increased sympathetic tone in patients with airways obstruction. However, Gibson and Sowton (1968) demonstrated a $16 \%$ reduction in pulse rate after intravenous I.C.I. 50,172 during submaximal exercise in healthy volunteers, and similar findings have been reported by Shinebourne, Fleming, and Hamer (1968) in hypertensive and ischaemic heart disease. Sowton, Balcon, Cross, and Frick (1968) showed a reduction in resting heart rate after I.C.I. 50,172 in ischaemic heart disease and suggest that resting sympathetic activity may be increased in these patients.

We are able to demonstrate a profound depression of isoprenaline-induced tachycardia with I.C.I. 50,172 and this confirms results obtained in anaesthetized animals (Dunlop and Shanks, 1968) and healthy volunteers (Brick et al., 1968). The marked reduction in palpitation in our series is probably related to the blockage of the inotropic effect in addition to the chronotropic effect of isoprenaline (Dunlop and Shanks, 1968). The ability of I.C.I. 50,172 to stop isoprenaline-induced ventricular extrasystoles was demonstrated in one patient in our series; a similar effect has been demonstrated in experimental ventricular fibrillation induced by chloroform and adrenaline in the cat (Dunlop and Shanks, 1968).

The clear-cut reduction in airways resistance after I.C.I. 50,172 indicates that there is some bronchial adrenergic blocking effect, and suggests caution in the use of this drug in patients with 
airways obstruction unless it is promptly followed by administration of a potent bronchodilator. These findings suggest that the effect of I.C.I. 50,172 on bronchial smooth muscle is greater in patients with airways obstruction than in experimental animals. Dunlop and Shanks (1968) found no significant interference with the bronchodilator action of isoprenaline in guinea-pigs after I.C.I. 50,172, although propranolol abolished the response.

Although the increase in F.E.V ${ }_{\cdot 1 \cdot 0}$ produced by isoprenaline was reduced by I.C.I. 50,172, a significant improvement $(P<0.01)$ in airways obstruction was obtained. A larger dose of isoprenaline might have produced a comparable increase in F.E.V $\cdot_{\cdot \cdot \cdot 0}$ after I.C.I. 50,172 without inducing significant tachycardia, but the similar final F.E.V.1.0 in the two parts of the study suggests that the limit of possible bronchodilatation may have been reached.
Our results indicate that I.C.I. 50,172 may be used to protect the patient from the side-effects of $\frac{\bar{\sigma}}{\bar{C}}$ adrenergic bronchodilators such as isoprenaline.

We are grateful to Dr. Neville Oswald for allowing us to study patients under his care.

\section{REFERENCES} Ahlquist, R. P. (1948). A study of the adrenotropic receptors. Amer. J. $\vec{\omega}$
Physiol., 153, 586.

Brick, I., Hutchison, K. J., McDevitt, D. G., Roddie, I. C., and Shanks, R. G. (1968). Comparison of the effects of I.C.I. 50172 and propranolol on the cardiovascular responses to adrenaline, $\vec{x}$ isoprenaline and exercise. Brit. J. Pharmacol., 34, 127.

Chamberlain, D. A. C. (1967). M.D. Thesis, University of Cambridge.

Dunlop, D., and Shanks, R. G. (1968). Selective blockade of adreno-. ceptive beta receptors in the heart. Brit. J. Pharmacol., 32, 201.

Gibson, D., and Sowton, E. (1968). Effects of I.C.I. 50172 in man $\vec{\sigma}$ during erect exercise. Brit. med. J., 1, 213.

Shinebourne, E., Fleming, J., and Hamer, J. (1968). Haemodynamic responses to exercise in hypertension: place of the sympathetic $\rightarrow$ nervous system evaluated by a new selective cardiac beta-adrenergic blocking agent ICI 50,172. Cardiovasc. Res., 2, 379.

Sowton, E., Balcon, R., Cross, D., and Frick, H. (1968). Haemo-ד dynamic effects of I.C.I. 50172 in patients with ischaemic heart $\overline{(D)}$ disease. Brit. med. J., 1, 215.

Speizer, F. E., Doll, R., Heaf, P., and Strang, L. B. (1968). Investiga- $\bar{\partial}$ tion into use of drugs preceding death from asthma. Ibid., 1, 339. 믄 